To cite: JD Mujuzi 'Private prosecution as a local remedy before the African Commission on Human and Peoples' Rights' (2019) 19 African Human Rights Law Journal 26-42 http://dx.doi.org/10.17159/1996-2096/2019/v19n1a2

\title{
Private prosecution as a local remedy before the African Commission on Human and Peoples' Rights
}

Jamil D Mujuzi*

Professor of Law, Faculty of Law, University of the Western Cape, South Africa

https://orcid.org/0000-0003-1370-6718

\section{Summary}

Article 56(5) of the African Charter on Human and Peoples' Rights provides that the African Commission on Human and Peoples' Rights will admit individual communications only if, inter alia, they '[a]re sent after exhausting local remedies, if any, unless it is obvious that this procedure is unduly prolonged'. The African Commission has developed rich jurisprudence around article 56(5). One of the issues that has started to emerge before the African Commission is whether or not a private prosecution is a domestic remedy that has to be exhausted before a person may file a communication before the Commission. Relying on the jurisprudence of the Human Rights Committee, the Committee against Torture, the Committee on the Elimination of All Forms of Racial Discrimination, the Inter-American Court of Human Rights and the European Court of Human Rights, the author suggests some of the ways in which the African Commission could deal with the issue of private prosecution as a domestic remedy. Specifically, the author argues that in order to determine whether or not a private prosecution is an effective remedy the African Commission may have to consider factors such as the person with locus standi to institute a private prosecution; funding to conduct a private prosecution; and how the public prosecutor has exercised or is likely to exercise the power to intervene in private prosecutions.

Key words: private prosecution; domestic/local remedy; African Commission; exhaustion; victim participation

LLB (Makerere) LLM (Pretoria) LLM (Free State) LLD (Western Cape); djmujuzi@gmail.com 


\section{Introduction}

The African Commission on Human and Peoples' Rights (African Commission) has the mandate to deal with inter-state ${ }^{1}$ and individual communications. ${ }^{2}$ Since its establishment it has dealt with hundreds of individual communications and a few inter-state communications. ${ }^{3}$ Before the African Commission declares an individual communication admissible the complainant, among other admissibility requirements, has to exhaust local or domestic remedies. Thus, article 56(5) of the African Charter on Human and Peoples' Rights (African Charter) provides that the African Commission will admit individual communications only if they '[a]re sent after exhausting local remedies, if any, unless it is obvious that this procedure is unduly prolonged'. The African Commission has developed a rich jurisprudence around article $56(5)^{4}$ and it is beyond the scope of this article to discuss that jurisprudence in detail. One of the issues that appears to be emerging from the jurisprudence of the African Commission is that of the private prosecution as a local remedy. Private prosecutions are provided for in many African countries and submissions have been made before the African Commission on whether or not the complainant should have instituted a private prosecution as a local remedy before approaching the African Commission. It is not far-fetched to argue that sooner or later the African Commission increasingly will have to deal directly with the issue of whether a private prosecution is an effective remedy that has to be exhausted before a person may file a communication before the Commission. In this article the author suggests ways in which the African Commission may establish whether or not a private prosecution was an effective remedy before declaring the communication admissible or inadmissible. The Commission's decisions have to be based on factors such as the law governing private prosecutions in a given country and the manner in which it is being implemented. In order to support the recommendations made in the article, the author demonstrates how other international and regional human rights bodies have dealt with private prosecution as a domestic remedy. The author first highlights the jurisprudence of the African Commission in which the issue of private prosecutions as a local remedy has been dealt with.

1 Arts 47-54 of the African Charter on Human and Peoples' Rights, adopted 27 June 1981, OAU Doc CAB/LEG/67/3 rev 5, 21 ILM 58 (1982), entered into force 21 October 1986.

2 Arts 55-59 African Charter.

3 See generally M Ssenyonjo (ed) The African regional human rights system: 30 years after the African Charter on Human and Peoples' Rights (2012); F Viljoen International human rights law in Africa (2012) 213-390.

4 Viljoen (n 3) 213-390. 


\title{
2 Jurisprudence of the African Commission on private prosecutions
}

The first communication in which the African Commission dealt with the issue of private prosecution as a local remedy, and also the only communication in which it has so far dealt with the issue of private prosecutions comprehensively, is Zimbabwe Human Rights NGO Forum $\checkmark$ Zimbabwe. ${ }^{5}$ In this communication the complainants argued that government agents had violated several human rights in the African Charter and committed criminal acts leading to the death of more than 80 people in the aftermath of the February 2000 constitutional referendum. ${ }^{6}$ In objecting to the admissibility of the communication, the Zimbabwean government argued that the complainants should have approached the Attorney-General to prosecute the suspects ${ }^{7}$ and that 'the complainant could have instituted private prosecutions against those persons alleged to have committed crimes and had not been prosecuted by the state' ${ }^{8}$ The complainants argued that they could not have instituted criminal proceedings against those alleged to have perpetrated the violations as the President had granted them immunity from prosecution through a clemency order. ${ }^{9}$ In dismissing the state's objection, the African Commission held that the state, through the police force, had the responsibility to maintain law and order, to investigate alleged criminal activity and to arrest those suspected of committing offences and hand them over to the relevant authorities for prosecution. ${ }^{10}$ The African Commission added: ${ }^{11}$

To expect victims of violations to undertake private prosecutions where the
state has not instituted criminal action against perpetrators of crimes or
even follow up with the Attorney-General what course of action has been
taken by the state as the respondent state seems to suggest in this matter
would be tantamount to the state relinquishing its duty to the very citizens
it is supposed to protect. Thus, even if the victims of the criminal acts did
not institute any domestic judicial action, as the guardians of law and order
and protectors of human rights in the country, the respondent state is
presumed to be sufficiently aware of the situation prevailing in its own
territory and therefore holds the ultimate responsibility of harnessing the
situation and correcting the wrongs complained of.

The African Commission added that the respondent state's concession that its criminal justice system did not have the capacity to investigate and prosecute all allegations of crime was an indication that 'domestic remedies may have been available in theory but as a matter of

\author{
(2006) AHRLR 128 (ACHPR 2006). \\ Zimbabwe Human Rights NGO Forum (n 5) paras 1-13. \\ Zimbabwe Human Rights NGO Forum paras $61 \& 68$. \\ Zimbabwe Human Rights NGO Forum para 62. \\ Zimbabwe Human Rights NGO Forum para 64. \\ Zimbabwe Human Rights NGO Forum para 70.
}

11 As above. 
practicality were not capable of yielding any prospect of success to the victims of the criminal assaults'. ${ }^{12}$

The above decision should be understood in light of the fact that there had been a breakdown of the rule of law in Zimbabwe and that the government had decided not to prosecute those alleged to have violated human rights and committed criminal acts. This decision was made because those acts had been committed by government officials or militias associated with the ruling party with the explicit or implied approval of senior public servants. In light of the fact that under Zimbabwean law a private prosecution cannot be instituted without a certificate from the Prosecutor-General (previously the Attorney-General) to the effect that he had declined to prosecute the alleged offenders, 13 it would have been unrealistic to expect the Attorney-General to issue such certificate for private prosecutions to be instituted against government officials or militias who had committed such acts to achieve or further government objectives. It should also be noted that in Zimbabwean law a public prosecutor is empowered to take over a private prosecution and either continue

\section{Zimbabwe Human Rights NGO Forum para 71.}

13 At the time when the communication was filed before the African Commission and when the African Commission handed down its decision, sec 16 of the Criminal Procedure and Evidence Act 2 of 2016 provided: '(1) Except as is provided by subsection (2), it shall not be competent for any private party to obtain the process of any court for summoning any party to answer any charge, unless such private party produces to the officer authorised by law to issue such process a certificate signed by the Attorney-General that he has seen the statements or affidavits on which the charge is based and declines to prosecute at the public instance, and in every case in which the Attorney-General declines to prosecute he shall, at the request of the party intending to prosecute, grant the certificate required.' However, in $2016 \mathrm{sec} 16$ was amended to give the Prosecutor-General more control over the process of instituting private prosecutions. The amended section provides: '(1) Except as is provided by subsection(4), it shall not he competent for any private party to obtain the process of any court for summoning any party to answer any charge, unless such private party produces to the officer authorised by law to issue such process a certificate signed by the Prosecutor-General that he or she has seen the statements or affidavits on which the charge is based and declines to prosecute at the public instance, and, subject to the conditions set forth in subsections (2) and (3), in every case in which the Prosecutor-General declines to prosecute he or she shall, at the request of the party intending to prosecute, grant the certificate required. (2) The Prosecutor-General shall grant the certificate referred to in subsection (1) if (a) there is produced to him or her by the private party a written request in the form of a sworn statement from which it appears to the Prosecutor-General that the private party (i) is the victim of the alleged offence, or is otherwise an interested person by virtue of having personally suffered, as a direct consequence of the alleged offence, an invasion of a legal right beyond that suffered by the public generally; and (ii) has the means to conduct the private prosecution promptly and timeously; and (iii) will conduct the private prosecution as an individual (whether personally or through his or her legal practitioner), or as the representative of a class of individuals recognised as a class for the purposes of the Class Actions Act ... and (b) no grounds exist in terms of subsection (3) for withholding the certificate. (3) The Prosecutor-General may refuse to grant the certificate referred to in subsection (1) upon any one or more of the following grounds, namely (a) that the conduct complained of by the private party does not disclose a criminal offence; or (b) that on the evidence available, there is no 
with it or discontinue it. ${ }^{14}$ Had the complainants been permitted to institute private prosecutions, one cannot rule out the possibility that public prosecutors would have taken over and discontinued them. Therefore, a private prosecution as a local remedy was not likely to be effective. However, the challenge is that the African Commission does not deal with Zimbabwean law on private prosecutions in reaching its conclusion whether or not it would have been an effective local remedy. One of the observations to be made about the above holding of the African Commission is the fact that in cases of massive or widespread human rights violations it is for the state to ensure that the violations are investigated and the perpetrators prosecuted. In other words, private prosecution is not an effective remedy in cases where state officials have been implicated in massive or widespread human rights violations.

The second communication in which the African Commission dealt with the issue of private prosecutions was Hadi $v$ Sudan. ${ }^{15}$ The respondent's police officers allegedly violated several African Charter rights, committed various criminal acts, and enjoyed immunity from prosecution. In its submissions the state argued that the complainant had not exhausted local remedies, for example, by failing to approach public prosecutors to prosecute the alleged perpetrators. ${ }^{16}$ The state also added that the Constitution guaranteed the complainant the right to litigation and that they should have invoked that right. ${ }^{17}$ The state did not expressly submit that victims had a right to institute a private prosecution. In response, the complainants submitted that

[t]he Criminal Procedure Code provides for the right to bring a private prosecution. However, such prosecution can only proceed with the approval of the head of the police forces who will need to lift the immunity of the individual officer(s) concerned. It is also subject to the approval of the Attorney-General ... [T] where the police, have not even commenced the initial investigation as in the present case. ${ }^{18}$

possibility (or only a remote possibility) of proving the charge against the accused beyond a reasonable doubt; or (c) whether the person to be prosecuted has adequate means to conduct a defence to the charge (in the case of any person who but for the fact that the Prosecutor-General has declined to prosecute him or her, would have qualified for legal assistance at the expense of the state); or (d) that it is not in the interests of national security or the public interest generally to grant the certificate to the private party. (4) When the right of prosecution referred to in this Part is possessed under any statute by any public body or person in respect of particular offences, subsections (1), (2) and (3) shall not apply.'

14 Sec 20 of the Criminal Procedure and Evidence Act provides that '[i]n the case of a prosecution at the instance of a private party, the Attorney-General or the local public prosecutor may apply by motion to any court before which the prosecution is pending to stop all further proceedings in the case, in order that prosecution for the offence may be instituted or continued at the public instance and such court shall, in every such case, make an order in terms of the motion'.

15 Abdel Hadi, Ali Radi \& Others $v$ Republic of Sudan Communication 368/09 (African Commission, 4 June 2014).

16 Hadi (n 15) paras 33-37.

17 Hadi para 38.

18 Hadi para 27. See also Hadi para 42. 


\section{The African Commission held: ${ }^{19}$}

The respondent state also admits that police officers in Sudan generally enjoy immunity which can only be lifted after a preliminary investigation. It does not also dispute the fact that there is no established procedure or right to compel the prosecution attorney to commence an investigation where there is an allegation of wrongdoing by the police, nor that as established above; an attempt at investigating the allegations was made. The Commission considers the granting of such blanket immunities to police officers as an impediment to the exhaustion of local remedies since it is not disputed that there is no legal obligation on the part of the police hierarchy to lift the immunities of these officers on demand. Because of the immunity granted to police officers, neither a private prosecution nor a civil suit could be brought against them unless such immunities were lifted, which immunities could only be lifted after a preliminary investigation.

Against that background the African Commission held that 'by failing to initiate an investigation into the complaints, the respondent state thereby made any local remedies that theoretically existed,

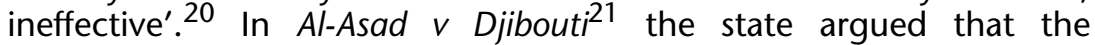
communication was inadmissible because the complainant had not exhausted local remedies, ${ }^{22}$ including 'criminal local remedies'. ${ }^{23}$ The complainant argued that 'the respondent state having failed to institute an effective investigation, even upon notice [of the violations] ... to the respondent state's Chief Prosecutor, he was and is under no obligation to bring private prosecution as a domestic remedy'. ${ }^{24}$ Although the African Commission declared the communication inadmissible, it did not address the issue of private prosecution.

The above jurisprudence shows that the issue of private prosecutions as a local remedy has started to be raised at the African Commission level. ${ }^{25}$ In its General Comment on article 5 of the African Charter, 26 the African Commission called upon African countries to ensure that victims of torture are empowered to institute

19 Hadi para 47.

20 Hadi para 48.

21 Mohammed Abdullah Saleh Al-Asad v the Republic of Djibouti Communication 383/ 10 (African Commission, 14 October 2014).

22 Al-Asad paras 83-88.

23 Al-Asad para 85.

24 Al-Asad para 71.

25 In their periodic reports some African countries have reported on cases in which private prosecutions have been instituted in cases such as forced marriage, sexual violence against minors, and gender-based violence (assault and battery perpetrated against women). See eg Initial Periodic Report of the Republic of Côte d'Ivoire (2012-2015) (2016) 14, http://www.achpr.org/files/sessions/59th/statereports/2nd-2012-2015/cote_divoire_periodic_report_2012_2015_eng.pdf (accessed 24 April 2019).

26 Art 5 of the African Charter provides that '[e]very individual shall have the right to the respect of the dignity inherent in a human being and to the recognition of his legal status. All forms of exploitation and degradation of man, particularly slavery, slave trade, torture, cruel, inhuman or degrading punishment and treatment shall be prohibited.' 
private prosecutions. ${ }^{27}$ The Commission is yet to find that a private prosecution is an effective local remedy that should have been exhausted by the applicant before he or she submitted a communication to the Commission. In order to rule that a private prosecution is an effective and available remedy the African Commission would have to analyse the legislation on private prosecutions in different African countries and the extent to which such legislation is implemented in practice. In light of the fact that different African countries have adopted different approaches to the issue of private prosecutions, each communication would have to be determined on the basis of the law and practice in a given country. It should be recalled that African countries have taken three broad approaches to the issue of private prosecutions. First, in some countries such as Kenya ${ }^{28}$ and The Gambia, ${ }^{29}$ private prosecutions are provided for in the Constitution. Second, in many countries, such as South Africa, Zimbabwe, Namibia, Rwanda and Uganda, private prosecutions are provided for in pieces of legislation. ${ }^{30}$ Finally, in some countries, such as Ghana, the law prohibits private prosecutions. ${ }^{31}$ There is still room for the African Commission to develop its jurisprudence on private prosecution as an effective local remedy especially in cases that do not involve massive human rights violations. In order to enrich its jurisprudence on private prosecutions the African Commission may also draw on the practice of international human rights bodies by invoking article 60 of the African Charter. This jurisprudence is discussed below.

27 General Comment 4 on the African Charter on Human and Peoples' Rights: The Right to Redress for Victims of Torture and Other Cruel, Inhuman or Degrading Punishment or Treatment (Article 5), adopted at the 21st extraordinary session of the African Commission on Human and Peoples' Rights, held from 23 February to 4 March 2017 in Banjul, The Gambia, para 75 provides that '[i]n line with state parties' obligations under article 7 of the African Charter, the option of private prosecution for acts of torture and other ill-treatment by non-state actors should be availed and sufficiently facilitated by the state when utilised by a victim, including by addressing practical challenges to private prosecution such as prohibitive costs or the impossibility in practice to access all relevant evidence', http://www.achpr.org/files/instruments/general-comment-right-to-redress/achpr_ general_comment_no._4_english.pdf (accessed 24 April 2019).

28 Art 157(6)(b) Constitution of Kenya. For a detailed discussion of the right to institute a private prosecution in Kenya, see JD Mujuzi 'Private prosecutions in Kenya' (2018) 11 African Journal of Legal Studies 33-70.

29 Arts 85(1)(c)(i) \& (ii) Constitution of The Gambia.

30 See generally JD Mujuzi 'The right to institute a private prosecution: A comparative analysis' (2015) 4 International Human Rights Law Review 222.

31 See secs 4 and 9 of the Criminal Procedure Code (Amendment) Act 633 of 2002 repealing secs 57 and 139 of the Criminal Procedure Code Act 30 of 1960. 


\section{International human rights bodies and private prosecution as a domestic remedy}

Some international human rights bodies have a mandate to receive individual communications alleging the violations of the rights provided for in the relevant treaties. One of the requirements that has to be met before such communications can be admissible is that the author or the complainant must first exhaust local remedies. Jurisprudence from some of these human rights bodies shows that private prosecution, where necessary, is one local or domestic remedy that has to be exhausted for a communication to be admissible. In this part of the article the author highlights the jurisprudence from the following human rights bodies relevant to the issue of private prosecutions as a domestic or local remedy: the Human Rights Committee; the Committee against Torture; the Committee on the Elimination of All Forms of Racial Discrimination; the Inter-American Court of Human Rights; the Inter-American Commission of Human Rights; and the European Court of Human Rights.

Article 60 of the African Charter requires the African Commission when interpreting the African Charter to 'draw inspiration from international law on human and peoples' rights' in particular those adopted by the African Union (AU), the United Nations (UN) and by African countries. The African Commission may invoke and has invoked article 60 of the African Charter to refer to jurisprudence from international human rights bodies. ${ }^{32}$ As mentioned above, before international human rights bodies such as the Human Rights Committee, $^{33}$ the Committee against Torture ${ }^{34}$ and the Committee against All Forms of Racial Discrimination ${ }^{35}$ may admit a communication, the petitioner has to exhaust domestic remedies unless such remedies are ineffective or unavailable. The issue of private prosecutions as a domestic remedy has been dealt with by some of these treaty bodies. In Dimitrijevic $v$ Serbia and Montenegro 36 the complainant approached the Committee against Torture because he had been ill-treated and tortured by the respondent's security agents. He submitted that he had reported the case to the public

32 See eg Law Offices of Ghazi Suleiman $v$ Sudan (II) (2003) AHRLR 144 (ACHPR 2003); Media Rights Agenda v Nigeria (2000) AHRLR 262 (ACHPR 2000); Darfur Relief and Documentation Centre v Sudan (2009) AHRLR 193 (ACHPR 2009); Noah Kazingachire, John Chitsenga, Elias Chemvura and Batanai Hadzisi (represented by Zimbabwe Human Rights NGO Forum) v Zimbabwe, Communication 295/04; Legal Resources Foundation v Zambia (2001) AHRLR 84 (ACHPR 2001); and Centre for Minority Rights Development \& Others v Kenya (2009) AHRLR 75 (ACHPR 2009).

33 Art 2 Optional Protocol to ICCPR.

34 Art 22(5)(b) Convention against Torture and Other Cruel, Inhuman or Degrading Treatment or Punishment (1984).

35 Art 14(2) International Convention on the Elimination of All Forms of Racial Discrimination.

36 Dimitrijevic $v$ Serbia and Montenegro, Communication 207/2002, UN Doc A/60/44 142 (CAT 2004). 
prosecutor who did not get back to him to inform him whether or not the allegations had been investigated. ${ }^{37}$ He submitted that in terms of the Criminal Procedure Code, if the public prosecutor comes to the conclusion that he will not investigate the alleged commission of an offence (request for a formal judicial investigation), he has to inform the victim in order for him to decide whether or not to institute a private prosecution. ${ }^{38} \mathrm{He}$ added that the Criminal Procedure Code does not stipulate the time within which the public prosecutor must decide whether or not he will 'request a formal judicial investigation' and in the absence of such a decision the victim cannot institute a private prosecution. ${ }^{39}$ He further argued that '[p]rosecutorial inaction following a complaint filed by the victim therefore amounts to an insurmountable impediment in the exercise' of his rights to institute a private prosecution and to access a court to have his case heard. ${ }^{40} \mathrm{He}$ added that the failure by the police and the public prosecutor to identify the alleged perpetrators meant that it was impossible for him to 'file for a formal judicial investigation'. 41 This is because the relevant provision of the Criminal Procedure Code (article 158(3)) provides that 'the person against whom a formal judicial investigation is requested must be identified by name, address and other relevant personal data' which details the applicant did not have. ${ }^{42}$ Against that background the Committee against Torture held: ${ }^{43}$

Concerning the alleged violation of articles 12 and 13 of the Convention, the Committee notes that the public prosecutor never informed the complainant about whether an investigation was being or had been conducted after the criminal complaint was filed on 31 January 2000. It also notes that the failure to inform the complainant of the results of such investigation, if any, effectively prevented him from pursuing 'private prosecution' of his case before a judge. In these circumstances the Committee considers that the state party has failed to comply with its obligation, under article 12 of the Convention, to carry out a prompt and impartial investigation wherever there is reasonable ground to believe that an act of torture has been committed. The state party also failed to comply with its obligation, under article 13, to ensure the complainant's right to complain and to have his case promptly and impartially examined by the competent authorities.

The Committee against Torture came to a similar conclusion in other communications. ${ }^{44}$ The jurisprudence from the Committee against

\footnotetext{
37 Dimitrijevic (n 36) paras 2.2-2.4.

38 Dimitrijevic para 2.5.

39 As above.

40 As above.

41 As above.

42 As above.

43 Dimitrijevic (n 36) para 5.4.

44 Besim Osmani v Serbia, Communication 261/2005, UN Doc A/64/44 289 (CAT 2009) para 5.7. See also the earlier decision of Dzemajl v Serbia and Montenegro, Communication 161/2000, UN Doc A/58/44 78 (CAT 2002) para 9.5; Dimitrijevic $v$ Serbia and Montenegro, Communication 172/2000, UN Doc A/61/44 144 (CAT 2005) para 7.3; Dimitrov $v$ Serbia and Montenegro, Communication 171/2000, UN Doc A/60/44 112 (CAT 2005) para 7.2.
} 
Torture shows that a state party has to investigate allegations of torture or ill-treatment and that if it is unwilling to prosecute the perpetrators it should make the findings of the investigation available to the victim so as to enable him or her to institute a private prosecution against the alleged perpetrators. The Human Rights Committee has also dealt with the issue of private prosecutions as a local remedy. In Andersen $v$ Denmark ${ }^{45}$ the complainant, a Muslim woman, alleged that some Danish politicians had made discriminatory and insulting comments about Muslim women contrary to Danish law. ${ }^{46}$ These politicians were not prosecuted by Danish authorities. Denmark argued that the petitioner should have instituted a private prosecution against the politicians and that 'choosing not to do so, she has failed to exhaust all available domestic remedies'. ${ }^{47}$ The author argued that 'private litigation is ... not by definition a remedy to secure the implementation by the state party of its international obligations'. 48 The Committee 'took note of the author's argument that private litigation is not by definition a remedy to secure the implementation by the state party of its international obligations' ${ }^{49}$ The Committee held that in the circumstances and according to Danish legislation, 'it would be unreasonable to expect the author to initiate' a private prosecution against the politicians. ${ }^{50}$ The Human Rights Committee came to a similar conclusion in a subsequent communication against Denmark. Similarly, in cases where discriminatory statements were publicly made by a politician and the public prosecutor declined to prosecute the politician in question the Committee on the Elimination of All Forms of Racial Discrimination held that it would have been unreasonable to expect the complainants to institute private prosecutions for the offences that had been committed in public and which, according to Danish law, should have been prosecuted by the public prosecutor. 51

The Human Rights Committee will declare a communication inadmissible if the complainant has not exhausted local remedies, including instituting a private prosecution if such a remedy is effective. In Hickey $v$ Australia ${ }^{52}$ the author's son died of injuries he sustained after falling off his bicycle when a police car was driving behind

45 Andersen $v$ Denmark, Communication 1868/2009, UN Doc CCPR/C/99/D/1868/ 2009, A/65/40, Vol II (2010), Annex VI 508 (HRC, 26 July 2010).

46 Andersen (n 45) para 2.1.

47 Andersen para 4.4.

48 Andersen para 5.6.

49 Andersen para 6.3.

50 As above.

51 Mohamad Adan v Denmark, Communication 43/2008, UN Doc CERD/C/77/D/43/ 2008, A/65/18(2010) Annex III 142 (CERD, 13 August 2010) para 6.3; Quereshi $v$ Denmark, Communication 33/2003, UN Doc A/60/18 142 (2005) para 6.3; Gelle v Denmark, Communication 34/2004, UN Doc A/61/18 124 (2006) para 6.5; Jama $v$ Denmark, Communication 41/2008, UN Doc A/64/18 123 (2009) para 6.5.

52 Hickey v Australia, Decision, Communication 1995/2010, UN Doc CCPR/C/111/D/ 1995/2010 (HRC, 21 July 2014). 
him. ${ }^{53}$ The police investigated the death and concluded that it had been an accident and that no police officer would be prosecuted. The coroner also concluded that there was no evidence to conclude that the action of the police contributed to the deceased's death. ${ }^{54}$ As a result no police officer was prosecuted for the alleged offence. In the complaint to the Human Rights Committee the author argued that the state had violated the son's right to life (under article 6 of ICCPR) and articles 2 and 26 because it had failed independently to investigate the circumstances leading to his death. The state argued that before approaching the Human Rights Committee the author should have instituted a private prosecution against those who had allegedly caused her son's death. ${ }^{55}$ In response to the state's submission on private prosecutions, the author argued that '[a] private prosecution in the circumstances of the present case would be very likely to be taken over or discontinued by the Director of Public Prosecutions and be dependent on the initial investigation'. ${ }^{56}$ The state argued that the author's 'comments on the possibility of a private prosecution action are only speculative and mere doubts about the action that can be taken by the Director of Public Prosecutions'.57 However, in this communication the Committee declared the communication inadmissible on the ground that the author should have challenged the coroner's findings locally before approaching the Human Rights Committee. ${ }^{58}$ The Committee did not deal directly with the question of whether the author should have instituted a private prosecution. If a complainant institutes a private prosecution, he has to wait for the outcome of that prosecution before he approaches the Human Rights Committee otherwise the communication will be declared inadmissible. ${ }^{59}$

The above jurisprudence from the international human rights bodies shows that a private prosecution is a domestic remedy only when it is effective and available. In determining whether or not it is effective and available, the relevant committee will examine the legislation governing private prosecutions in a given country. This is an approach that the African Commission may have to adopt when confronted with communications alleging that private prosecutions should have been instituted before the complainants approached the African Commission. It should be emphasised that treaties impose obligations on state parties and not on individuals. Therefore, a state party has a duty to ensure that human rights are protected, promoted and fulfilled. This duty should not be relegated to human rights

\footnotetext{
53 Hickey (n 52) paras 2.1-2.2.

54 Hickey para 2.5.

55 Hickey para 4.10.

56 Hickey para 5.4.

57 Hickey para 6.3.

58 Hickey para 8.4.

59 Jama v Denmark, Communication 41/2008, UN Doc A/64/18 123 (2009) para 4.6.
} 
victims by expecting them to institute private prosecutions in cases where human rights violations also amount to criminal acts in domestic legislation.

Apart from the UN human rights bodies, some regional human rights bodies have also dealt with the issue of private prosecutions as a domestic remedy. Article 46(1)(a) of the American Convention on Human Rights ${ }^{60}$ provides that before the Inter-American Commission of Human Rights or the Inter-American Court of Human Rights admits a communication the petitioner has to ensure 'that the remedies under domestic law have been pursued and exhausted in accordance with generally recognized principles of international law'. The InterAmerican Court of Human Rights and the Inter-American Commission of Human Rights have developed rich jurisprudence on article $46(1)(a){ }^{61}$ but a discussion of this jurisprudence falls outside the scope of this article. The article will deal with those communications in which private prosecutions have been dealt with as a domestic remedy.

In Luisiana Rios Paiva $v$ Venezuela ${ }^{62}$ the complainants alleged that they had been subjected 'to several threats, acts of harassment, and verbal and physical abuse, including injuries caused by gunshots' by state officials. ${ }^{63}$ In objecting to the admissibility of the communication, the respondent state argued that

in the cases of alleged verbal attacks (threats, libel and slander) and damages to the property, given that these are crimes of a private prosecution the alleged victims should have turned directly to the trial court and legally filed a private accusation, since the Public Prosecutors' Office is prevented from investigating these crimes ex officio. ${ }^{64}$

Without directly addressing the issue of private prosecutions the Court found that Venezuela had violated several provisions of the Convention. ${ }^{65}$ The Inter-American Court and the Inter-American Commission have held that a complainant should not be expected to institute a private prosecution if the alleged offence could be prosecuted only by a public prosecutor. ${ }^{66}$ In Gayle $v$ Jamaica ${ }^{67}$ the petitioners argued that the state had violated the deceased's right to life because he had died as a result of injuries inflicted on him by the

60 Adopted at the Inter-American Specialized Conference on Human Rights, San José, Costa Rica, 22 November 1969.

61 JM Pasqualucci The practice and procedure of the Inter-American Court of Human Rights (2012) 92-98.

62 Luisiana Rios Paiva v Venezuela, Judgment (IACtHR, 28 January 2009).

63 Luisiana Rios Paiva (n 62) para 2.

64 Luisiana Rios Paiva para 34.

65 Luisiana Rios Paiva para 416.

66 Laura Susana Alban-Cornejo v Ecuador, Judgment (IACtHR, 22 November 2007) para 92; Vera-Vera \& Others $v$ Ecuador, Judgment, Series C 226 (IACtHR, 19 May 2011) 94; Parada Cea v El Salvador, Case 10.480, Inter-Am CHR, Report 1/99, OEA/Ser.L/V/II.106, doc 6 rev (1999) para 119.

67 Gayle v Jamaica, Petition 191/2002, Inter-Am CHR, Report 8/03, OEA/Ser.L/V/ II.118, doc 5 rev 2 (2003). 
respondent's security forces. ${ }^{68}$ The state argued that the petition was inadmissible for failure to exhaust domestic remedies, including the institution of a private prosecution against the perpetrators. ${ }^{69}$ In response the petitioner acknowledged that although Jamaican law provided for circumstances in which a person may institute a private prosecution, the following were some of the challenges the author would have faced had he decided to institute a private prosecution: the Constitution empowers the Director of Public Prosecutions to take over and either continue or discontinue such a prosecution; a private prosecution cannot be instituted without the consent or authorisation of the Director of Public Prosecutions; and the Director of Public Prosecutions was unlikely to allow the applicant to institute a private prosecution as he had already expressed the view that there was insufficient evidence to secure a conviction. ${ }^{70}$

The state in response argued that the law provided for the remedy of private prosecution and that the petitioner had failed to adduce evidence to prove that had he instituted a private prosecution the Director of Public Prosecutions would have taken it over in order to prevent him from continuing with it. ${ }^{71}$ Against that background the state argued that the petitioner had not exhausted domestic remedies and that, therefore, the Commission should declare the petition inadmissible. $^{72}$

In rejecting the state's submission, the Commission referred to the Jamaican Constitution and held that in Jamaica the Director of Public Prosecutions 'has exclusive authority' for 'making all decisions concerning criminal prosecutions arising in Jamaica'. This authority meant that he could take over a private prosecution and either continue with it or discontinue it. ${ }^{73}$ According to the Commission this provision meant that the 'state retains exclusive authority for pursuing criminal proceedings in respect of the circumstances relating to [the deceased]'. ${ }^{74}$ Against that background, the Commission held: ${ }^{75}$

While the record indicates that there is provision under Jamaican law for 'private prosecutions', the Commission considers that proceedings of this nature do not constitute remedies that the petitioners are required to exhaust. It is clear from the instruments and decisions of the InterAmerican system ... that the obligation to investigate, prosecute and punish serious violations of human rights rests with member states, as the entities with the international legal commitment and resources to carry out these functions. To expect the petitioners to assume these responsibilities would not only be inconsistent with the system's jurisprudence, it would

\footnotetext{
68 Gayle (n 67) para 2.

69 As above.

70 Gayle (n 67) para 13.

71 Gayle para 26.

72 As above.

73 Gayle (n 67) para 43.

74 As above.

75 As above.
} 
also place an inequitable burden on those who generally lack the means and expertise to fulfil these responsibilities.

On the issue of judicial review, the Commission held: ${ }^{76}$

The Commission similarly considers that an application for judicial review in respect of the DPP's decision not to prosecute criminal charges in relation to [deceased's] death does not constitute an effective remedy that the petitioners should be required to pursue for the purposes of the exhaustion of domestic remedies requirement. It reaches this conclusion in light of the fact that the ability of an individual to pursue application for judicial review requires the granting of leave by the Jamaican Supreme Court which, according to the information available, is a discretion that is exercised by the Court infrequently, as well as the fact that, even where successful, the relief available appears to be limited to an order requesting the DPP to reconsider his or her decision not to prosecute.

In Garcia Garcia $v$ Ecuador ${ }^{77}$ the Inter-American Commission on Human Rights held that private prosecution as a domestic remedy is not available if the law does not provide for circumstances in which the petitioner could institute such a prosecution. The petitioner's application to be a private prosecutor in a military court had been dismissed by the Military Court of Justice as 'the Military Code of Criminal Procedure does not provide for private prosecution'. ${ }^{78}$ The state's argument that the decision of the Military Court of Justice could be reversed on appeal was rejected by the Commission because 'during the criminal proceedings in the military courts, the alleged victim's family was unable to be a prosecuting party thereto. As a result, they were unable to raise the respective claims before the authorities hearing the case. ${ }^{79}$ The Commission reiterated its position that 'special courts, such as those of the military or police, are not an appropriate forum and thus are not the appropriate remedy to investigate, try and punish potential violations of the human rights enshrined in the American Convention' ${ }^{80}$

Article 35(1) of the European Convention of Human Rights provides that '[t]he Court may only deal with the matter after all domestic remedies have been exhausted, according to the generally recognised rules of international law'.81 The European Court of Human Rights in several decisions has held that a private prosecution will be a domestic

76 Gayle (n 67) para 44.

77 Garcia Garcia v Ecuador, Report 84/12, Petition 677-04 (IACmHR, 8 November 2012).

78 Garcia (n 77) para 12.

79 Garcia para 41.

80 Garcia para 37.

81 For a discussion of the relevant case law on art 35(1), see European Court of Human Rights Practical guide on admissibility criteria (2018) 21-28, https:// www.echr.coe.int/documents/admissibility_guide_eng.pdf (accessed 25 April 2019). 
remedy if it is effective. ${ }^{82}$ For example, the Court held that where the government failed to intervene to prevent and stop the applicant's neighbours from violating her rights under article 3 of the European Convention on Human Rights the government had failed to show that the applicant's institution of a private prosecution against her neighbours 'could lead to such an intervention [by the government] and effective resolution of the underlying systemic problem' ${ }^{83}$ The Court held that depending on the facts of the case it is dealing with, 'where the domestic law provided for public criminal prosecution, it is not for the Court to speculate on whether the applicant's criminal complaint should have been pursued by way of private prosecution' 84 The legal framework that provides for public prosecutions and also for the possibility of a victim of human rights violations instituting a private prosecution should the public prosecutor decline to prosecute provides for 'sufficient protection' ${ }^{85}$ The Court held that for a private prosecution to be an effective and adequate domestic remedy, the state has to prove that 'it was capable of providing any redress to the applicant in relation to the complaint' in question. ${ }^{86}$ Also, a private prosecution will be an effective remedy if there is evidence of previous successful private prosecutions. ${ }^{87}$ The mere fact that the accused was acquitted in a private prosecution does not mean that the private prosecution was not an effective domestic remedy. The European Court of Human Rights held that ' $[t]$ he mere fact that the outcome of those [private] criminal proceedings was not in the applicant's favour, does not render them ineffective'. ${ }^{88}$ The applicant is not required to appeal against an unfavourable judgment in a private prosecution matter before approaching the European Court of Human Rights. ${ }^{89}$ Where there are other ways in which the applicant could bring the 'substance of his complaint to the notice of the national authorities' and unsuccessfully followed those ways, he or she is not expected to institute a private prosecution if it 'would have had the same objective as' the first remedy he sought. ${ }^{90}$ In cases of human rights violations by

82 Abdu v Bulgaria (Application 26827/08) 11 March 2014 para 36; Bazjaks v Latvia (Application 71572/01) 19 October 2010 para 125; Borbála Kiss v Hungary (Application 59214/11) 26 June 2012 para 26; and Denizci \& Others $v$ Cyprus (Applications 25316-25321/94 and 27207/95) 23 May 2001 paras 355-357; Irina Smirnova v Ukraine (Application 1870/05) 13 October 2016 para 77; MF v Hungary (Application 45855/12) (31 October 2017) para 35; Tarjáni v Hungary (Application 29609/16) (10 October 2017) paras 30-31.

83 Irina Smirnova v Ukraine (Application 1870/05) 13 October 2016 para 77.

$84 \check{Z ̌ B} v$ Croatia (Application 47666/13) (11 July 2017) para 60.

85 Alković v Montenegro (Application 66895/10)(5 December 2017) para 68.

86 Bazjaks v Latvia (Application 71572/01) 19 October 2010 para 91.

87 Egmez v Cyprus (Application 30873/96) 21 December 2000 para 99; Haász and Szabó v Hungary (Applications 11327/14 and 11613/14) 13 October 2015 para 28; Heino v Finland (Application 56720/09) 15 February 2011 para 53.

88 Borisov v Lithuania (Application 9958/04) 14 June 2011 para 125.

89 MF v Hungary (n 82) paras 32-37.

90 Tarjáni v Hungary (n 82) para 30. See also Škorjanec v Croatia (Application 25536/ 14) (28 March 2017) para 46. 
government officials, the Court held that 'victims are not required to pursue the prosecution of officers accused of ill-treatment on their own, this being a duty of the public prosecutor who is certainly better, if not exclusively, equipped in that respect' ${ }^{\prime 91}$

The above jurisprudence shows the circumstances in which a private prosecution may or may not be an effective domestic remedy. As in the case of the other human rights bodies discussed above, the European Court of Human Rights will also examine the law and practice of the state party to determine whether or not the private prosecution was an effective remedy. The African Commission may find some of the jurisprudence of the European Court above relevant should it be confronted with communications dealing with private prosecutions as a domestic remedy.

\section{Conclusion}

This article has dealt with the issue of private prosecution as a domestic remedy before the African Commission and other international and regional human rights bodies. It has been illustrated that the African Commission so far specifically has dealt with the issue of private prosecution in a single communication. However, there have been other communications in which authors have submitted that private prosecution was not an effective local remedy that should have been exhausted before a communication was filed with the African Commission. In these communications the African Commission has not dealt directly with the issue of private prosecution. In light of the fact that African countries have adopted different approaches to the issue of private prosecutions the African Commission would have to analyse the law and practice in a given country to decide whether or not a private prosecution was an effective domestic remedy in need of exhaustion before a complainant can approach the Commission. Sometimes the mere fact that there is a possibility to institute a private prosecution does not mean that it is an effective remedy. For example, some victims of human rights violations may be bribed to withdraw a private prosecution. In one communication before the Human Rights Committee, for example, there were allegations that the parents of a child who had been sexually assaulted were bribed to withdraw a private prosecution against the perpetrator. ${ }^{92}$ It is recommended that in assessing whether or not a private prosecution is an effective remedy the African Commission may consider the following factors (the list is not exhaustive). First is the issue of a person with locus standi to institute a

91 Haász and Szabó v Hungary (Applications 11327/14 and 11613/14) 13 October 2015 para 30. See also Jasiński v Poland (Application 72976/01) 6 December 2007 para 28.

92 HLC $v$ Serbia, Communication 1355/2005, UN Doc A/62/40, Vol II 525 (HRC 2007) para 2.8 . 
private prosecution. One of the questions to be asked in this regard is whether another person, including a juristic person, may institute a private prosecution on behalf of the victim of crime. Private prosecutions may be costly and some victims of crime may not be willing or be able (financially or otherwise) to institute private prosecutions. $^{93}$ It is important that the right to institute private prosecutions is extended to natural and juristic persons, even if they are not individually affected by the offence in question, who may be willing and able to prosecute the alleged offenders. This extension will enable non-governmental organisations (NGOs), for example, to fundraise and institute private prosecutions on behalf of some victims. Second, and related to the first issue, is the issue of funding to conduct a private prosecution. As mentioned above, private prosecutions are expensive and many victims of crime may not have the necessary resources to finance such prosecutions. If there is no legal aid for such victims or if they are unable to raise funds from other sources, a private prosecution is out of their reach and, therefore, unavailable as a remedy. The third factor is how the public prosecutor has exercised or is likely to exercise the power to intervene in private prosecutions. If there is evidence to show that the private prosecutor is likely to take over and discontinue the private prosecution without any convincing reason or that in the past he or she has taken over private prosecutions and discontinued them or merely did not continue without a convincing reason, then a private prosecution is not an effective remedy. ${ }^{94}$ However, a public prosecutor could take over and discontinue a private prosecution in order to prevent the private prosecutor from using such a prosecution to abuse the court process.

93 In Ndlovu v S 201710 BCLR 1286 (CC); 2017 (2) SACR 305 (CC) para 58 (fn 39) the South African Constitutional Court held that '[i]n the event that the Director of Public Prosecutions declines to prosecute an alleged offence, a private person with a substantial and peculiar interest in a matter may apply to the NPA [National Prosecuting Authority] for a certificate nolle prosequi (refusal to prosecute) in terms of section 7(1)(a) of the Criminal Procedure Act. This certificate is required for a private person to institute a private prosecution, however instituting a private prosecution is prohibitively expensive.'

94 This has been the case, eg, in Uganda where the Director of Public Prosecutions took over private prosecutions and merely did not continue with them. See, generally, JD Mujuzi 'Strengthening the right to institute a private prosecution in Uganda by amending article 120(3) of the Constitution: A comment on Uganda $v$ Inspector-General of Police, General Kale Kayihura \& 7 Others (17 August 2016)' (2017) 25 African Journal of International and Comparative Law 589. 